\title{
Vegetation Response to Climate Change and Human Impacts in the Usambara Mountains
}

\author{
C. T. Mumbi, ${ }^{1,2}$ R. Marchant, ${ }^{1}$ and P. Lane ${ }^{3}$ \\ ${ }^{1}$ Environment Department, York Institute for Ecosystem Dynamics (KITE), University of York, Heslington, York, YO10 5DD, UK \\ ${ }^{2}$ Tanzania Wildife Research Institute (TAWIRI), P.O. Box 661, Arusha, Tanzania \\ ${ }^{3}$ Department of Archaeology, University of York, King's Manor, York YO 17 EP, UK
}

Correspondence should be addressed to C. T. Mumbi; cassian.mumbi@tawiri.or.tz

Received 4 December 2013; Accepted 18 February 2014; Published 29 May 2014

Academic Editors: S. Davey, J. F. Mas, and M. Vitale

Copyright (C) 2014 C. T. Mumbi et al. This is an open access article distributed under the Creative Commons Attribution License, which permits unrestricted use, distribution, and reproduction in any medium, provided the original work is properly cited.

\begin{abstract}
East and West Usambara Mountain blocks are unique based on three characteristics. Firstly, they are connected blocks; secondly, they have an oceanic-influenced climate; and thirdly, the rain seasons are not easily discernible due to their close proximity to the Indian Ocean and Equator. Sediment cores were collected from peat bogs in Derema (DRM) and Mbomole (MBML) in East Usambara and from Madumu (DUMU) in West Usambara. The multiproxy record provides an understanding on climate and vegetation changes during the last 5000 years. DRM and MBML cores result in radiocarbon ages and age-depth curve which showed hiatus at $20 \mathrm{~cm}$ and $61 \mathrm{~cm}$ and huge inversion for DUMU core at $57 \mathrm{~cm}$. Period $5000-4000{ }^{14} \mathrm{C}$ yr BP for DUMU core revealed increased Montane forest indicative of relatively moist conditions. Periods 3000-2000 and 2000-1000 ${ }^{14} \mathrm{C}$ yr BP, DUMU core demonstrated increased submontane and lowland forests. Period $1000-200{ }^{14} \mathrm{C}$ yr BP, DUMU core signified increased coprophilous fungi while DRM and MBML cores signified fluctuating herbaceous pollen spectra (wet-dry episodes). Period $200{ }^{14} \mathrm{C}$ yr BP to present, all cores demonstrated stable recovery of forest types especially dominance of submontane forests. Abundant coprophilous fungi indicated increased human impacts including forest fires, cultivation, and grazing.
\end{abstract}

\section{Introduction}

The Eastern Arc Mountains comprise thirteen separate blocs with their location stretching from south-east Kenya through south-central Tanzania (Figure 1). They are situated between $3^{\circ} 20^{\prime}$ to $8^{\circ} 45^{\prime} \mathrm{S}$ latitude and $35^{\circ} 37^{\prime}$ to $38^{\circ} 48^{\prime} \mathrm{E}$ longitude covering an area of around $3300 \mathrm{~km}^{2}$ of submontane, montane, and upper montane forests, which is less than $30 \%$, or some $1440 \mathrm{~km}^{2}$, of the estimated original forested area [1]. Their unique characteristic geological formation of isolation and connectivity played a crucial role in shaping the current distribution of species diversity within and between the mountain blocs. So to say, the Eastern Arc Mountains exhibit connectivity and isolation within blocks crucial to its existence. Connectivity is where blocs were formed as sister blocs were separated by a narrow gap without much difference in forest types. Connected mountain blocs include North and South Pare, West and East Usambara, North and South Uluguru, and the Udzungwa, all in Tanzania. The vice versa is true for the isolated mountain blocs; these include Nguu, Nguru, Ukaguru, Rubeho, Mahenge, Malundwe, and Uvidunda in Tanzania; Taita hills are an isolated bloc, the only mountain bloc in Kenya with an estimated remnant forested area of $6 \mathrm{~km}^{2}$ (Figure 1).

The Eastern Arc Mountains are evolutionary and ecologically quite distinct from adjacent highlands, grasslands, savannas, and woodlands in East Africa. They have more affinity to Guineo-Congolian lowland rainforests [2]. The Eastern Arc Mountains have been proposed as one of several refugia in Africa during geologic periods when the climate in tropics was generally unfavourable for forest development [3] (Hamilton [4]). This suggestion is based upon three lines of evidence: (1) the large numbers of species and endemics; (2) the centres of distribution for many disjunct species; and (3) declining species diversity with increasing distance from these regions. The three lines of evidence lack strong backing from the palaeoenvironmental point-of-view, that is, knowledge on past changes in the Eastern Arc Mountains. 


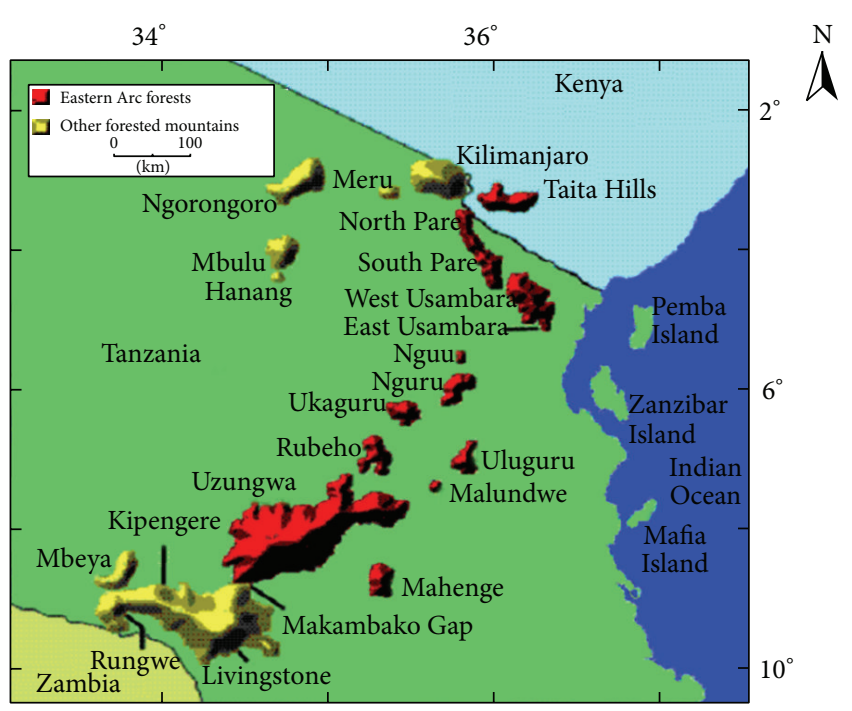

Figure 1: Map showing 12 Eastern Arc Mountain blocs in Tanzania and 1 in Kenya. Also shown are other tropical mountain blocs in Tanzania (adapted from [1]).

The first sedimentary record from this Mountain ecosystem was published in Mumbi et al., [5].

The climate of Eastern Arc Mountains is regulated by the topography of its blocs. Related to topography, two factors largely influence the weather and climate, namely, the Indian Ocean and Intertropical Convergence Zone (ITCZ). The influence of the Indian Ocean is determined by the distance from the mountain blocs, which brings about differences in the amount of precipitation and temperature variations between the blocs. They are located some $40 \mathrm{~km}$ from the Indian Ocean in East Usambara to $450 \mathrm{~km}$ in Udzungwa Mountains. The ITCZ influence determines seasonality, variability, and reliability in terms of annual rainfall and variability in terms of annual temperatures between the mountain blocs. The steep sloping eastern sides are generally wetter than the gentle sloping western sides of all the mountain ranges. The distance from the Indian Ocean determines the amount of annual precipitation, not temperature as the latter is influenced locally with the changing altitude. Within connected blocks, East Usambara is generally wetter than West Usambara; South Pare is wetter than North Pare; and South Uluguru is wetter than North Uluguru. Between isolated blocs, East and West Usambara are wetter than Nguru Mountains; North and South Uluguru are wetter than Udzungwa and Mahenge. The northern blocs have more oceanic-influenced climate having a few kilometers from the Indian Ocean compared to southern blocks which are both oceanic and continental influenced in daily, monthly, and annual rainfall and temperatures.

In East Usambara and West Usambara the rain seasons are not easily discernible partly because of its close proximity to the Indian Ocean and also to equator [7], while moving westwards and southwards, rain seasonality is clear. In some forest areas of East and West Usambara Mountains, there are three rain seasons. Short rainy season occurs from October to December based on Northeast trade winds. Long rains

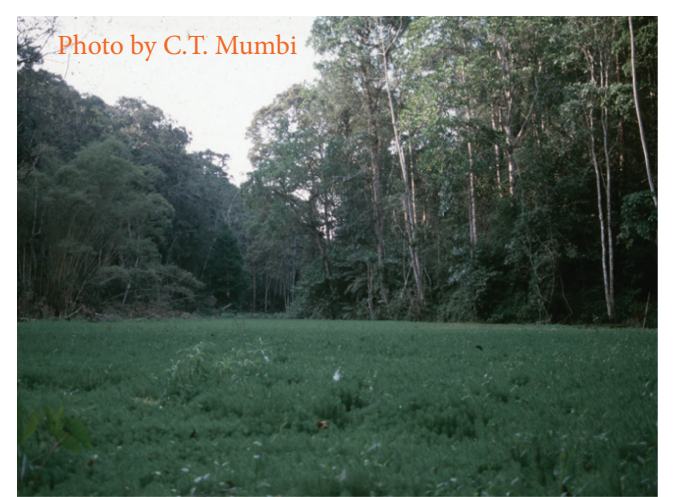

Figure 2: Amani pond showing the floating vegetation and the surrounding forest trees.

occur from March to May mainly convectional and the third rain occurs from July to August based on Southeast trade winds [7-9]. In Udzungwa and other southern mountain ranges, there is one long rainy season relatively constant from November to May [10]. Average rainfall measures at $1800 \mathrm{~mm} \mathrm{yr}^{-1}$. Mean annual temperatures measure at $22^{\circ} \mathrm{C}$ (maximum) during December and $17^{\circ} \mathrm{C}$ (minimum) during July. Generally, in all mountain ranges, frosts occur during July, which is the driest month of the year.

The main objective of the study in the Eastern Arc Mountains in Tanzania is to reconstruct vegetation changes from a hitherto underresearched area using several proxies, to infer environmental and climate change. The current hypothesis on the long-term ecological functioning of forest ecosystems in the Eastern Arc Mountains will be evaluated, in particular the claim that the biodiversity relates to longterm ecosystem stability. Sediment cores were collected from peat bogs in Derema and Mbomole (East Usambara) and Madumu (West Usambara). The multiproxy record provides an understanding on climate and vegetation changes across the interglacial-glacial periods.

\section{Materials and Methods}

\subsection{Study Sites: Description of Swamps}

(a) Amani Pond (Altitude: $870 \mathrm{~m}$ a.s.l; $05^{\circ} 07^{\prime} \mathrm{S}, 38^{\circ} 40^{\prime}$ E). This is a man-made pond constructed in 1902 during German colonial period. It is cut through by a stream that used to be a swimming pool (Figure 2).

(b) Derema Swamp (Altitude: 935 m a.s.l., $05^{\circ} 07^{\prime}$ S, $38^{\circ} 40^{\prime}$ E). This swamp (Figure 3 ) is located near the Derema Tea Estate in the Integrated Business Community (IBC) area of Msasa village. Derema corridor is a proposed IBC area in the Amani Nature Reserve (ANR).

\section{Dominant Vegetation Zones of Derema Swamp}

(i) Swamp (Bog) Vegetation. The main vegetation types on the swamp floors are Cyperus alopecuroides, Typha latifolia, Paepalanthus sp. (Papyrus). Ferns include Polypodium sp., 


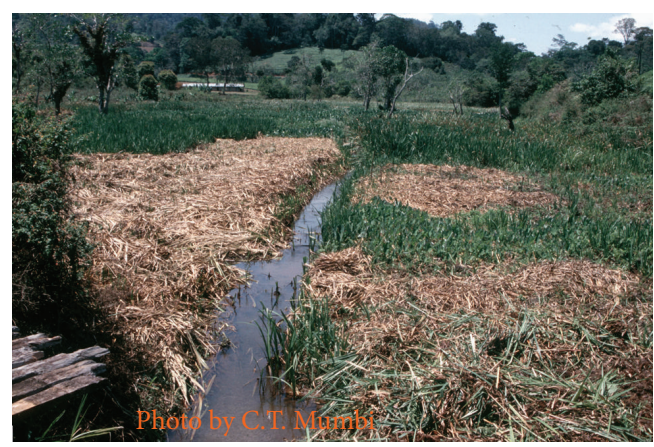

FIGURE 3: Derema Swamp area showing part of an actively cultivated area proposed as an integrated business community area.

Pteridium sp. and Thelypteris serrata on the swamp floors. Another fern, Cyathea manniana is also found along the valley banks, roads and disturbed forest areas. Along the edge of the swamp are few stands of the African mountain bamboo (Sinarundinaria alpina) and Dracaena demesne.

(ii) Transition Zone. These are found between the swamps and the regional vegetation. Shrubs, herbs, and climbers include Commelina benghalensis, Justicia insularis, Lantana camara, Ludwigia leptocarpa and Piper umbellatum; and grasses such as Andropogon sp., and Digitaria diagonalis. Cultivated plants include Mussa capensis, Trifolium odonata, Psidium guava, Camellia sinensis (Tea) and Cinnamomum sp. (Cinnamon), and Elettaria cardamomum (Cardamon).

(iii) Forest Area Vegetation. The regional vegetation includes Allanblackia stuhlmannii, Beilschmiedia sp., Cephaelasphaera usambarensis, Chrysophyllum gorungosanum, Credemia hirta, Ficus natalensis, Isoberlinia sp., Macaranga kilimandscharica, Maesa lanceolata, Maesopsis eminii, Melianthus holistii, Milicia excelsa, Myrianthus holistii, Newtonia buchananii, Ocotea usambarensis, Psidium africana, Strombosia scheffleri, Syzygium guineense, Tarbanaemontana pachysiphon, and Voacanga africana.

(c) Mbomole Swamp (Altitude: 935 m a.s.l., $05^{\circ} 07^{\prime} \mathrm{S}, 38^{\circ} 40^{\prime} \mathrm{E}$ ). This swamp is located just $1.5 \mathrm{~km}$ away from Derema Swamp. It is also located near Derema Tea Estate in the Integrated Business Community (IBC) area of Msasa village. For vegetation description, see Derema Swamp vegetation.

(d) Madumu Swamp (Altitude: $950 \mathrm{~m}$ a.s.l., $04^{\circ} 58^{\prime} \mathrm{S}$, $38^{\circ} 25^{\prime} \mathrm{E}$ ). A catchment swamp (Figure 4) fed by inflowing water and sediments via Vurumi River originating from West Usambara Mountains. This swamp forms part of the south-western edge of Vugiri plateau located at $950 \mathrm{~m}$ a.s.l. altitude. The diameter of the swamp is approximately $2 \mathrm{~km}$. The swamp area is used by local people in the surrounding villages of Chekereni and Makuyuni for cultivating Saccharum officinarum (Sugar cane), Oryza sativa (Rice), and Amaranthus chlorostachys (Amaranth). It is frequently burnt for this purpose for the large part of it.

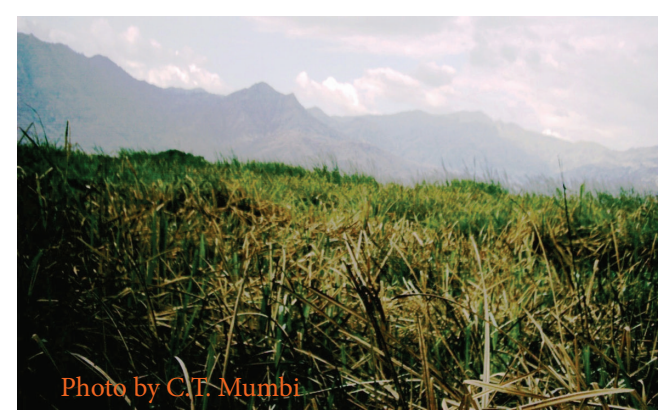

Figure 4: Madumu Swamp showing a far part of Vugiri plateau where Vurumi stream originates that flows into this swamp.

Vegetation Description. The swamp area is dominated by Cyperaceae, Ludwigia leptocarpa, and Typha latifolia. The area surrounding the swamp is cultivated mainly for Agave sisalana (Sisal), Zea mays (Maize), Phaseolus vulgaris (Kidney beans), Oryza sativa (Rice), and Amaranthus chlorostachys (Amaranth).

2.2. Sampling Procedure. Sediment cores were raised from three sedimentary basins in the Eastern Arc Mountain ranges; these include Derema and Mbomole (East Usambara) and Madumu (West Usambara) Catchment areas in Usambara Blocs. Sediments were collected using a $50 \mathrm{~mm}$ diameter Russian sampler. Sediment cores were wrapped in plastic, fixed with PVC guttering, and transported to York for storage in the dark at $4^{\circ} \mathrm{C}$. Lithological changes were described along the cores before sampling for pollen and radiocarbon dating. Sediment samples of $2 \mathrm{~cm}^{3}$ were taken at $2 \mathrm{~cm}$ intervals along the profile for pollen analysis. For preparing the pollen samples, we used the standard pretreatment technique, including sodium pyrophosphate, acetolysis, and heavy liquid separation with bromoform. Exotic Lycopodium spores were added before treatment to each sample to calculate the pollen concentration [11-15].

Chronological control is provided by using Accelerator Mass Spectrometry (AMS) radiocarbon dating on samples. Ages were calibrated to calendar years using PC-Based software Radiocarbon Calibration Program Calib Rev 4.4.2 [6]. The cores applied are Derema, Mbomole, and Madumu.

For pollen identification, we used morphological descriptions published by the African Pollen Database (APD) [11], [12-15]. For identification of fungal spores, the morphological descriptions published by Van Geel et al. [16, 17] were used. We used a pollen sum of minimally 300 pollen grains from regional vegetation. Pollen grains from aquatic taxa and spores of ferns, mosses, fungi, and algae were excluded from the pollen sum. According to altitudinal and ecological preference, taxa were classified into three groups: upper montane herb and shrub, upper montane forest, and montane forest (Table 1). Clusters of similar pollen spectra were identified using CONISS; the results were used to delimit pollen zones. Results were plotted using PC-based software TILIA and TILIA GRAPH [18]. 
TABLE 1: Specific data of AMS ${ }^{14}$ C samples from cores DRM, MBML and DUMU. Calibration of radiocarbon years is based on Calib Rev 4.4.2 [6].

\begin{tabular}{lcccr}
\hline Sample Depth $(\mathrm{cm})$ & Sample Code & ${ }^{14} \mathrm{C}$ yr BP & Interpolated age $(\mathrm{cal} \mathrm{yr} \mathrm{BP})$ & $\delta^{14} \mathrm{C}$ \\
\hline Derema-20 & GrA-33279 & no age & 100 & -20.50 \\
Derema-40 & GrA-33071 & $195 \pm 35$ & 190 & -23.81 \\
Derema-61 & GrA-33073 & no age & 225 & -28.18 \\
Derema-110 & GrA-33075 & $265 \pm 35$ & 260 & -24.92 \\
Derema-160 & GrA-33076 & $285 \pm 35$ & 290 & -26.23 \\
Mbomole-20 & GrA-33279b & no age & 100 & -20.31 \\
Mbomole-40 & GrA-33071b & $195 \pm 35$ & 190 & -23.53 \\
Mbomole-61 & GrA-33073b & no age & 230 & -26.69 \\
Dumu-25 & GrA-33662 & $2680 \pm 45$ & 2600 & -13.54 \\
Dumu-57 & GrA-33077 & $185 \pm 35$ & 3500 & -15.43 \\
Dumu-90 & GrA-33663 & $4315 \pm 45$ & 4300 & -13.81 \\
\hline
\end{tabular}

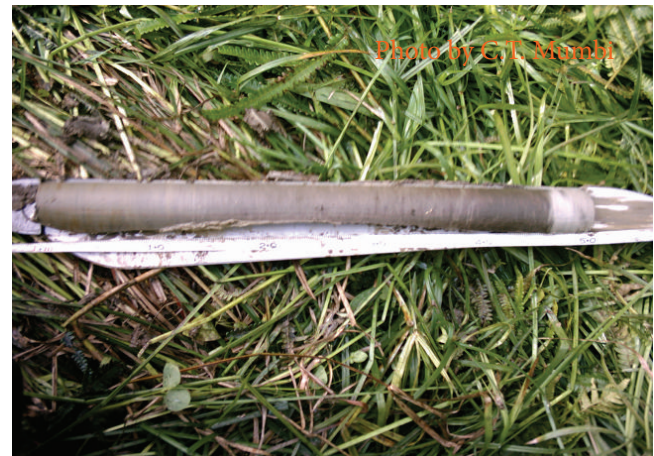

Figure 5: Derema core showing lithological changes between 50$100 \mathrm{~cm}$ sediment profiles.

\section{Results}

\subsection{Lithology and Chronology}

(a) Lithological Descriptions (Abbreviated Cores: Derema (DRM) (Figure 5), Mbomole (MBML), and Madumu (DUMU), (Figure 6))

(i) Amani Pond (was not analysed due to large hiatus/break in sediment core)

Grey in colour

0-40 cm: water

40-91 cm: sediments.

(ii) DRM core I

0-50 cm: decomposed peat/grey/fibrous material

$50-100 \mathrm{~cm}$ : clay material/grey material

$100-150 \mathrm{~cm}$ : dark lamination on top/sand at bottom/grey material.

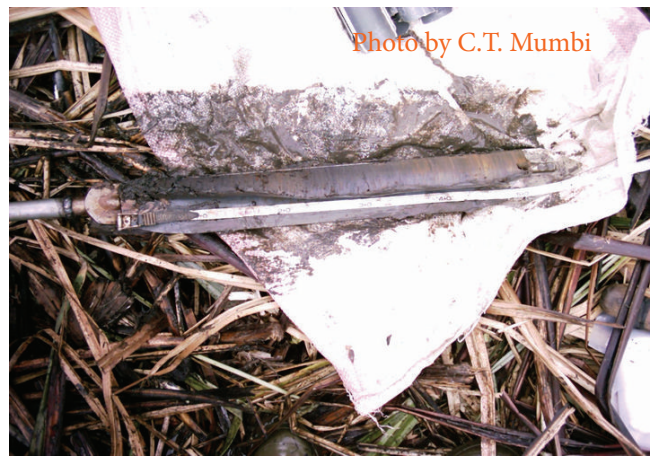

FIgURE 6: Dumu core showing lithological changes between 50 and $100 \mathrm{~cm}$ sediment profile.

(iii) DRM core II

0-50 cm: decomposed peat/fibrous/grey/very loose material

50-100 cm: decomposed peat/grey/fibrous/fibrous/loose material

100-150 cm: decomposed peat/light yellowish material

150-180 cm: fine sand/grayish material.

(iv) MBML core

MBML core I

0-30 cm: decomposed peat material $30-43 \mathrm{~cm}$ : coarse sand material $43-50 \mathrm{~cm}$ : decomposed peat material $50-100 \mathrm{~cm}$ : decomposed peat on top, coarse, sand material at the bottom;

MBML core II

0-10 cm: decomposed peat material $10-30 \mathrm{~cm}$ : fine sand material $30-50 \mathrm{~cm}$ : dense material/dark grey material 


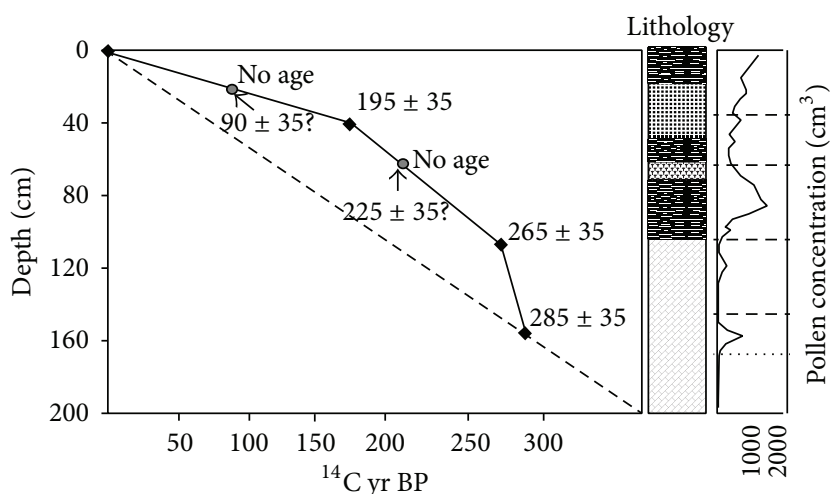

Yellow clay, organic-rich material

Yellowish clay, less organic-rich material

Light grey, sandy-clay material

Brown to dark decomposed peat with abundant plant fragments

FIgURE 7: Construction of age-depth curves for DRM and MBML cores.

50-100 m: decomposed peat on top, coarse, sand particles at the bottom.

(v) DUMU core

DUMU I

$0-20 \mathrm{~cm}$ : decomposed peat/dark in colour/fibrous material

$20-50 \mathrm{~cm}$ : dark-yellowish/fine sand/calcareous material

50-90 cm: dark-yellowish/fine sand/calcareous material;

\section{DUMU II}

0-20 cm: decomposed peat/very dark/ fibrous material

$20-50 \mathrm{~cm}$ : dark-yellowish/fine sand/calcareous material

50-100 cm: dark/grey/fine sand material.

The sediment characteristics and radiocarbon ages are presented in Figures 7 and 9. Radiocarbon results show that the ages of the DUMU core are the longest dated $4315 \pm$ $45{ }^{14} \mathrm{C}$ yr BP at $90 \mathrm{~cm}$ depth. This is the generally agreed onset of late Holocene period ( $4000 \mathrm{yr}$ BP to present). Results are graphed in a depth versus time plot (Figures 7, 8, and 9). The DUMU core age at $57 \mathrm{~cm}$ shows an inversion of almost 1000 radiocarbon years. The younger age $185 \pm 35{ }^{14} \mathrm{C} \mathrm{yr} \mathrm{BP} \mathrm{cm}$ may be explained by two reasons. Firstly, a contamination by possibly Cyperaceous roots that penetrate deeper and cause older sediments to reflect younger age, and secondly an erosional effect that displaced bottom/older sediments and replaced it with top/younger sediments. In general, the depth versus time curves of all cores show relatively similar sediment accumulation rates. An interpolated time scale in

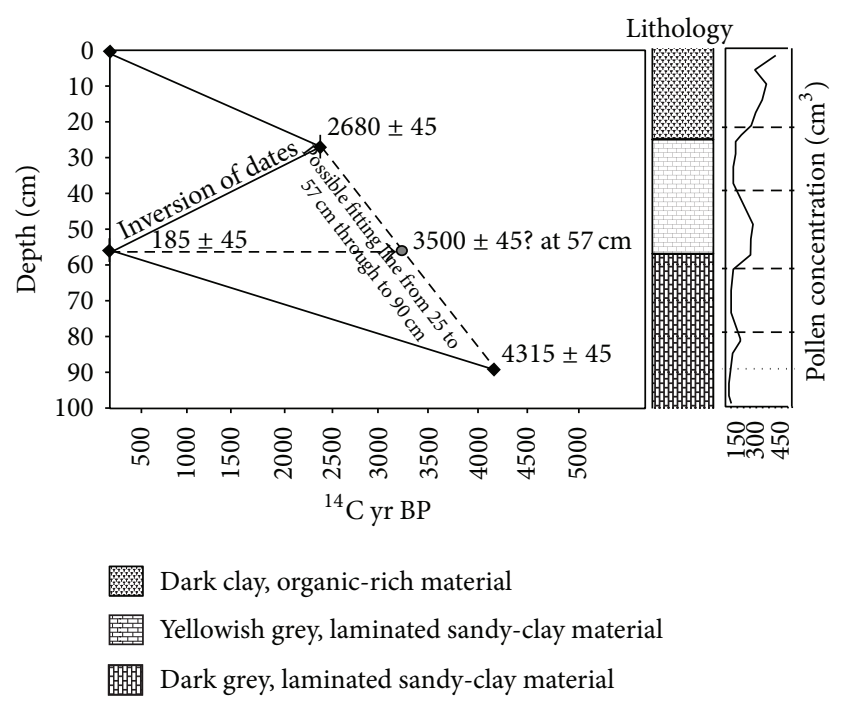

FIGURE 8: Construction of age-depth curves for DUMU core.

calendar age (cal yr BP) for each core was obtained by using the ages of core depth indicated in Table 1.

\subsection{Chronologies}

(a) DRM and MBML Cores. DRM and MBML cores results on radiocarbon ages and age-depth curve do not show an inversion common to other cores (Figure 7). However, they present a totally different problem; there is a loss of ages at depths $20 \mathrm{~cm}$ and $61 \mathrm{~cm}$ possibly due to contamination. The tricky situation here is even on the difficulty in providing reasons for contamination. The sediments at these depths are yellowish clay, rich in organic matter, which suggest a combination of many contaminating factors, bearing in mind the natural setting of an area. Hard water effect from parent rock, bioturbation, and human-related contamination (e.g., lipids) could be responsible for the loss of dates.

(b) DUMU Core. The results of radiocarbon ages from DUMU core showed that the middle ages hugely invert the depth versus time relationship at $57 \mathrm{~cm}$ (Figure 8). The sample was taken at the interval between yellowish gray, laminated sand-clay sediments (due to the contribution of parent rock due to carbon effect) and dark gray laminated sand-clay (due to the contribution of organic matter), at radiocarbon date $\left(185 \pm 45{ }^{14} \mathrm{C}\right.$ yr BP). As for the above inversions, the relatively young age could be caused by contaminations of young samples through the occurrence of vertical migration of datable components in the sediment sequence. Lipids, humics and fluvics, and insoluble carbon, or the hard water effect could be responsible for DUMU core.

3.3. Pollen Zonation and Construction of Diagrams. Pollen zones and constructed diagrams for cores DRM, MBML, and 


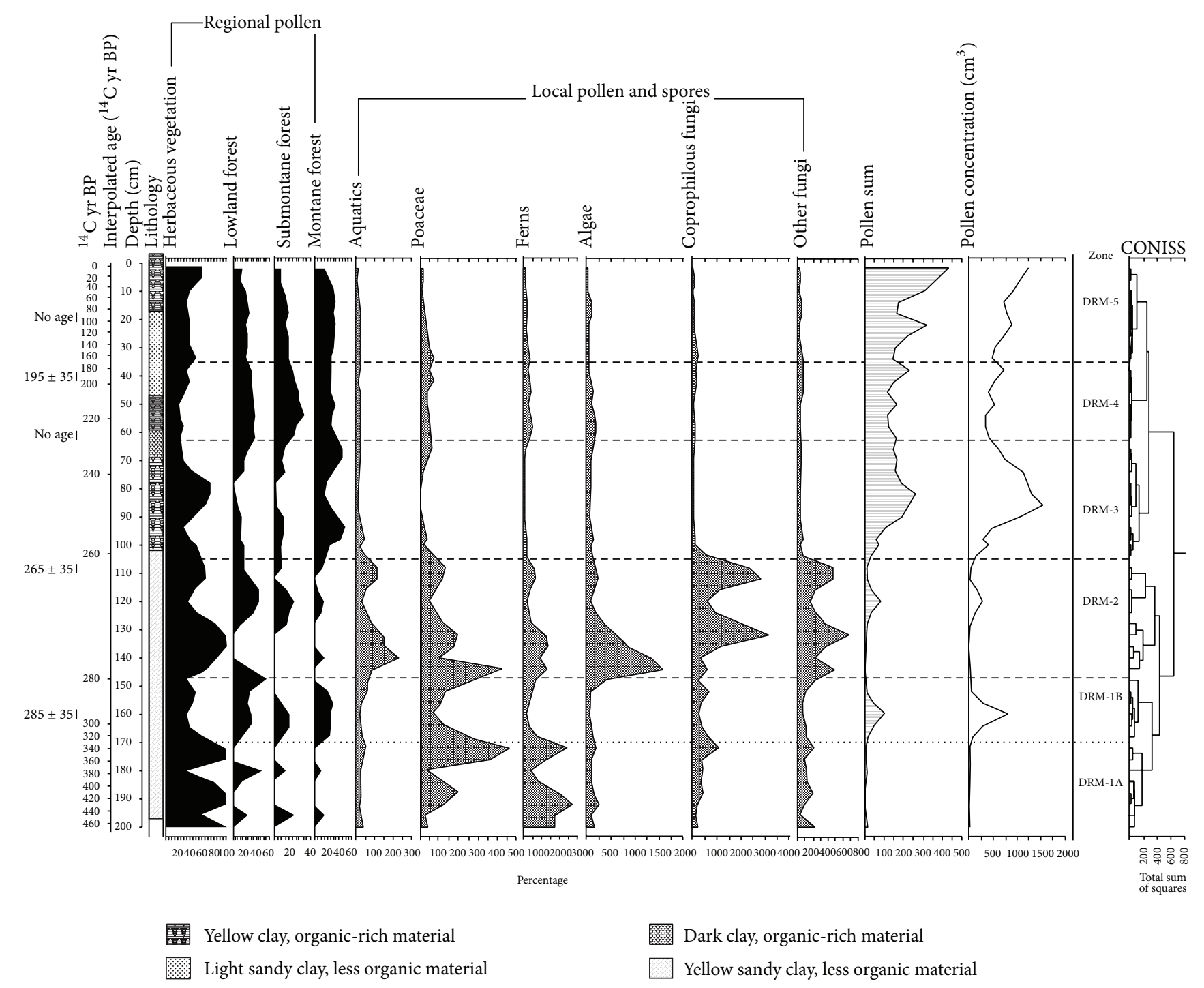

FIGURE 9: Summary diagram DRM core showing radiocarbon ages, interpolated scale of estimated ages, depth scale, down core changes of the main forest belts (regional pollen), local pollen and spores, pollen sum, pollen concentration, pollen zones, and CONISS cluster dendrogram.

DUMU are shown in Figures 9, 10, and 11. The interpretation of pollen diagrams follows in Section 4.

\section{(a) DRM Core}

Pollen Zone DRM-1A (200-170 cm, 460-340 ${ }^{14}$ C yr BP). This zone is characterized by representation of high percentages of herbaceous vegetation, Poaceae, and ferns. The main forest types (regional pollen) that include lowland, submontane, and montane vegetation types are represented by low percentages, as do algal and fungal groups (Figure 9).

Pollen Zone DRM-1B (170-145 cm; $340-280{ }^{14}$ C yr BP). This zone is characterized by representation of increased percentages of the main forest types (regional pollen) that include lowland, submontane, and montane vegetation types. Algal and fungal groups also showed a slight increase. Herbaceous vegetation, Poaceae, and ferns are represented by low percentages.
Pollen Zone DRM-2 (145-105 cm; $280-260{ }^{14} \mathrm{C}$ yr BP). This zone is characterized by higher proportions of all vegetation types than other pollen zones in this record. Herbaceous vegetation, Poaceae, ferns, algae, and fungal spores score higher percentages. Increased percentages also are shown by the main forest types (regional pollen) that include lowland, submontane, and montane vegetation types.

Pollen Zone DRM-3 (105-61 cm; 260-230 ${ }^{14}$ C yr BP). This zone is characterized by higher proportions of Herbaceous and Montane vegetation types. This increase is reflected in the pollen sum and concentration as they show higher proportions in this pollen zone compared to other pollen zones. Poaceae, ferns, algae, and fungal spores show decreased percentages.

Pollen Zone DRM-4 (61-35 cm; 230-170 ${ }^{14}$ C yr BP). This zone is characterized by high percentages of herbaceous, lowland, submontane, and montane vegetation types . Poaceae, ferns, 


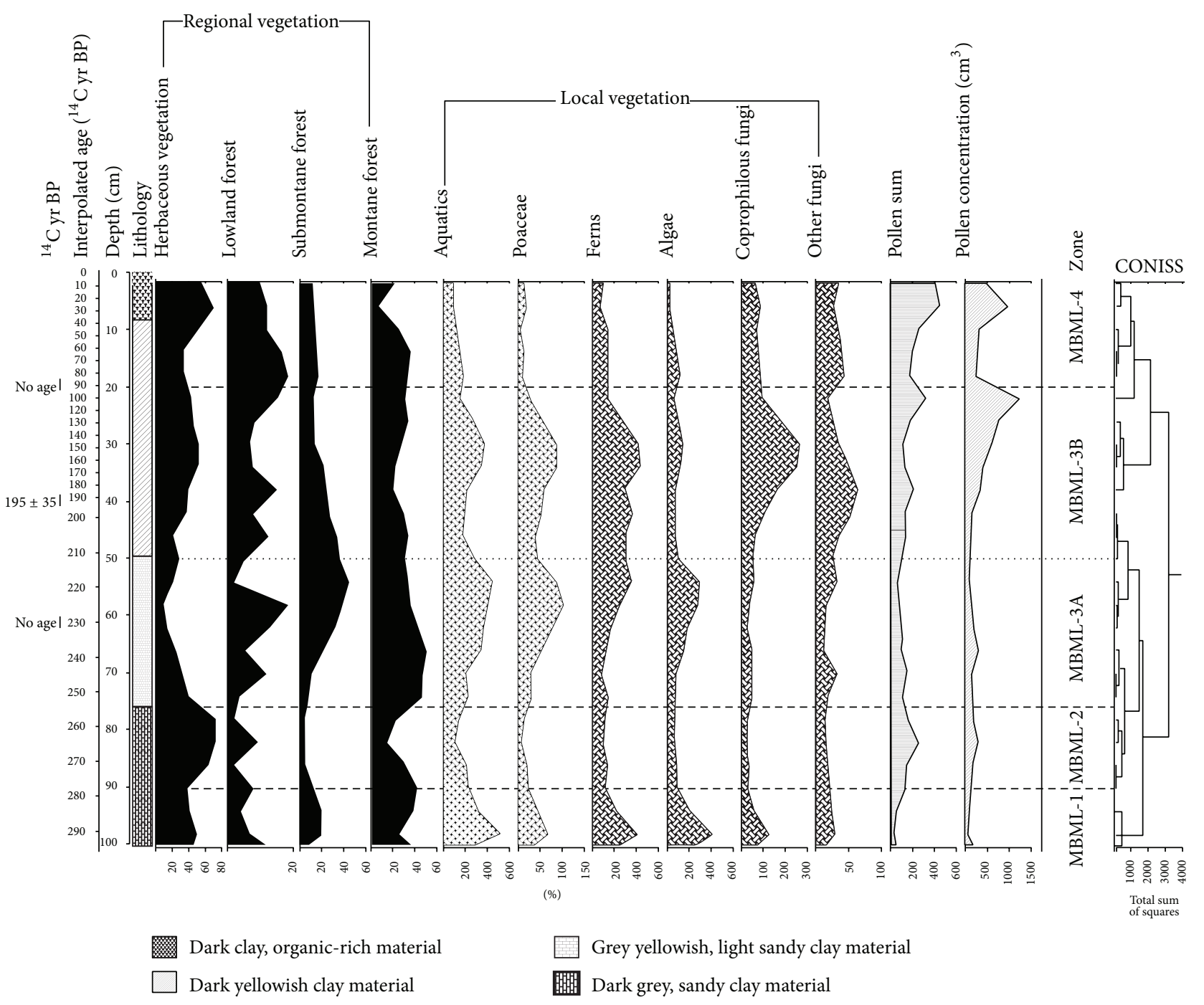

FIGURE 10: Summary diagram MBML core showing radiocarbon ages, interpolated scale of estimated ages, depth scale, down core changes of the main forest belts (regional pollen), local pollen and spores, pollen sum, pollen concentration, pollen zones, and CONISS cluster dendrogram.

algae, and fungal spores show low percentages. Pollen sum and pollen concentration showed relatively constant proportions.

Pollen Zone DRM-3 (35-0 cm; $170{ }^{14}$ C yr BP to Present). This zone is characterized by high percentages of herbaceous, lowland, submontane, and montane vegetation types. Poaceae, ferns, algae, and fungal spores show low percentages. Pollen sum and pollen concentration showed increased proportions.

\section{(b) MBML Core}

Pollen Zone $1\left(100-90 \mathrm{~cm}, 300-275{ }^{14} \mathrm{Cyr} \mathrm{BP}\right)$. This zone is characterized by high percentages of all vegetation types. High representation is particularly shown by montane vegetation, aquatic vegetation, ferns, algal, and fungal spores (Figure 10).

Pollen Zone $2\left(90-78 \mathrm{~cm}, 275-265{ }^{14} \mathrm{C} y r\right.$ BP). This zone is characterized by representation of highest percentages of herbaceous vegetation than any other pollen zone in MBML record. Apart from lowland vegetation type which showed low-high percentage interchanges, all other vegetation types showed low percentages.

Pollen Zone $3 A\left(78-50 \mathrm{~cm}, 265-215{ }^{14}\right.$ C yr BP). This zone is characterized by representation of highest percentages of montane forest with also increased submontane and lowland forest types. Aquatics, ferns, algae, and fungal spores showed increased percentages towards the top of the zone. Herbaceous vegetation showed the lowest percentages than any other pollen zone in MBML record.

Pollen Zone 3B (50-20 cm, 215-100 ${ }^{14}$ C yr BP). Herbaceous vegetation, lowland, and montane forest types showed increasing percentages. Submontane forest type showed a gradual decrease. The high percentages of herbaceous vegetation and forest types are reflected in the pollen sum and pollen concentration. These vegetation types make up the pollen 


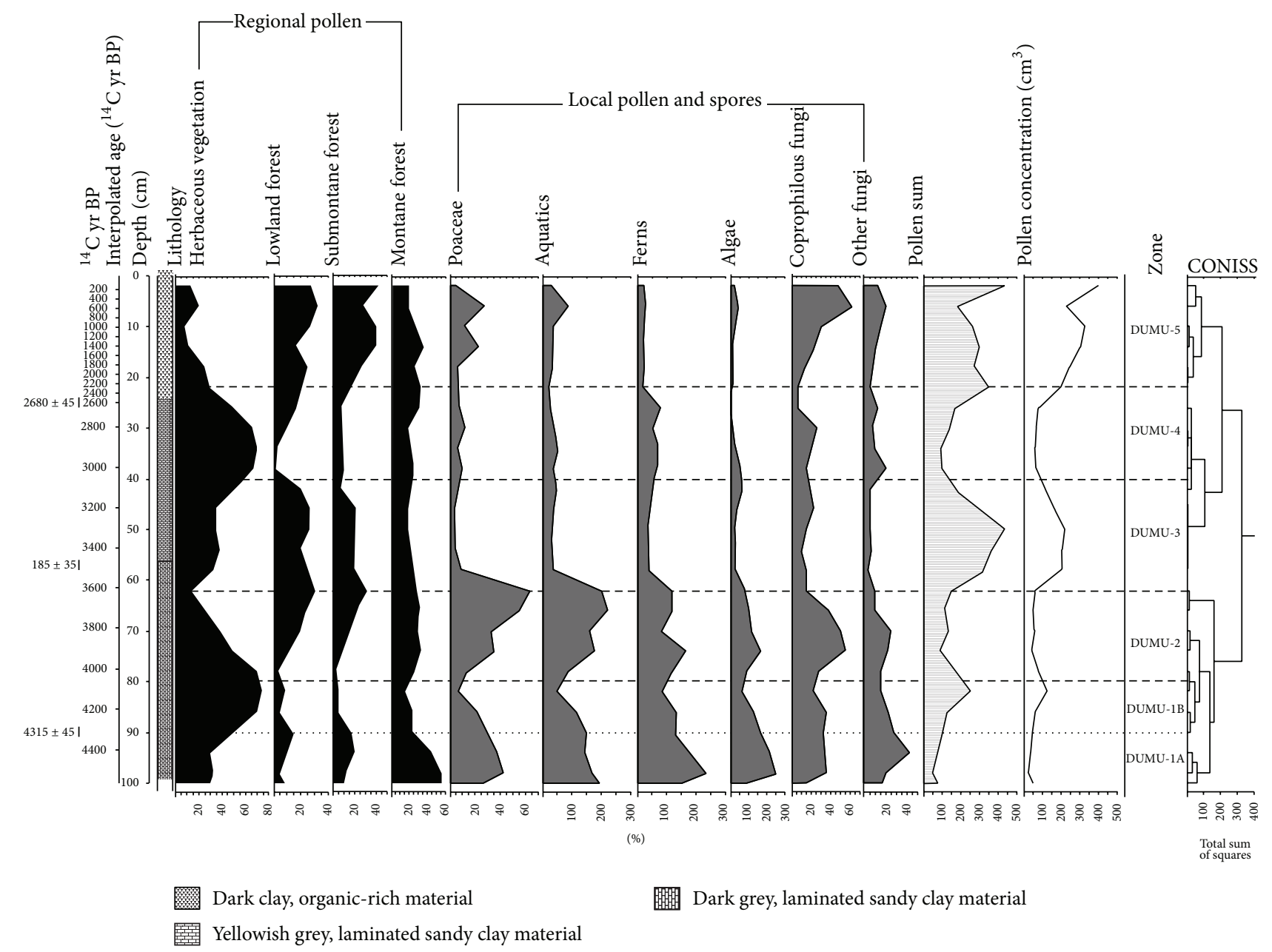

FIGURE 11: Summary diagram DUMU core showing radiocarbon ages, interpolated scale of estimated ages, depth scale, down core changes of the main forest belts (regional pollen), local pollen and spores, pollen sum, pollen concentration, pollen zones, and CONISS cluster dendrogram.

sum. Local vegetation (aquatics, ferns, algae, and fungal spores) showed higher percentages, with coprophilous fungi scoring the highest percentages than in any other zone.

Pollen Zone $4\left(20-0 \mathrm{~cm}, 100-0^{14} \mathrm{Cyr} B P\right)$. The high percentages of herbaceous vegetation and forest types are reflected in the pollen sum and pollen concentration. Local vegetation (aquatics, ferns, algae, and fungal spores) showed lower percentages.

\section{(c) DUMU Core}

Pollen Zone 1A (100-90 cm, 4600-4300 ${ }^{14} \mathrm{Cyr} B P$ ). This zone is characterized by the highest percentages of montane forest types than in any other zone; herbaceous vegetation also showed high percentages. Lowland and submontane forest types showed low percentages. The local vegetation (Poaceae, aquatics, algae, and fungi) showed increased percentages; this is reflected in the pollen sum and pollen concentration.

Pollen Zone $1 B\left(90-80 \mathrm{~cm}, 4300-4050{ }^{14} \mathrm{Cyr}\right.$ BP). The herbaceous vegetation showed highest percentages, and because it is included in the pollen sum, its dramatic increase is reflected. The main forest types showing decreased percentages and the local vegetation showed lower percentages (Figure 11).

Pollen Zone $2\left(80-62 \mathrm{~cm}, 4050-3600{ }^{14} \mathrm{Cyr} \mathrm{BP}\right)$. This zone is characterized by sharp decrease in percentages of herbaceous vegetation as opposed by sharp increase in percentages of local vegetation. Main forest types showed gradual increase in percentages. Pollen sum and concentration showed a gradual decrease in proportions.

Pollen Zone $3\left(62-40 \mathrm{~cm}, 3600-3050{ }^{14} \mathrm{C} y \mathrm{r} \mathrm{BP}\right)$. This zone is characterized by increased percentages of main forest types with gradual increase in herbaceous vegetation. In particular, lowland vegetation showed highest percentages than in any other zone. Local vegetation showed lowest percentages than in any other zone. This is supported by higher proportions of pollen sum and concentration.

Pollen Zone $4\left(40-22 \mathrm{~cm}, 3050-2300{ }^{14} \mathrm{C}\right.$ yr BP). This zone showed similar characteristics as in pollen zone $1 \mathrm{~B}$. The 
herbaceous vegetation showed highest percentages, and because it is included in the pollen sum, its dramatic increase is reflected. The main forest types are showing decreased percentages and the local vegetation showed lower percentages.

Pollen Zone $5\left(22-0 \mathrm{~cm}, 2300{ }^{14}\right.$ C yr BP to Present). This zone is characterized by remarkable increased percentages of main forest types and coprophilous fungi. The local vegetation groups of Poaceae and aquatics also showed gradual increase. Herbaceous vegetation showed a sharp increase towards the top of the zone. Pollen sum and concentration showed highest proportions in this zone reflective of increased percentages of main forest types.

\section{Discussion}

This section provides an interpretation of pollen spectral changes as explained in pollen zones for DRM, MBML, and DUMU cores. An approach will be to travel through time scales as provided by radiocarbon dating results encompassing all the cores where the period in interpretation is concerned. For the purpose of providing a summarized interpretation, the following time scales (periods) will be used: 5000-4000, 4000-3000, 3000-2000, 2000-1000, 1000200 , and $200-0{ }^{14} \mathrm{C}$ yr BP. The periods will be interpreted in light of the existing inferred palaeoenvironmental records in East Africa during the Late Holocene.

4.1. Period $5000-4000{ }^{14} \mathrm{C}$ yr BP. This period deals with DUMU core in which it is characterized with higher proportions of montane forest and local vegetation which can be indicative of relatively moist conditions at the higher altitude areas of East and West Usambara. Water table in swamps in the higher altitude areas could have been higher that favoured submerged plants. In East Africa, most records indicated the end of "African humid period" that brought about drier conditions [19-21]. This period is coincident with the "First Dark Age," the period of the greatest historically recorded drought in tropical Africa where some lakes (L. Victoria) dried up, which apparently extended to the Middle East and western Asia (cf. [21-25]). In some lake records, intervals of dry and wetter conditions were reported [21, 24, 26, 27].

4.2. Period 4000-3000 ${ }^{14} C$ yr BP. The DUMU record shows conditions that were dryer than the previous period and all the proceeding periods. The period showed that montane forest type and herbaceous vegetation were higher in abundance, an indication that there were forest remnants at the high altitude areas probably related to moisture supply from the Indian Ocean. The inferred conditions indicate there was an abrupt aridity regarding the fact that all the vegetation types indicated low percentages. In East African region, the longer and more extensive drought event at $\mathrm{c}$. 4000-3000 ${ }^{14} \mathrm{C}$ yr BP was registered in both the pollen and diatom records at different sites (Hamilton, [4]) [25, 28, 29]. However, Taylor [30] observed that expansions of dry forest taxa around Ahakagyezi and Muchoya occurred after ca 3900 and $3400 \mathrm{yr} \mathrm{BP}$, respectively.
4.3. Period $3000-2000{ }^{14} \mathrm{C}$ yr BP. The period in DUMU core demonstrates the recovery of the forest vegetation types with sharp reduction in herbaceous vegetation indicative of dominance of submontane and lowland forests. This has been explained by a temperature rise which caused the clouds to be formed at a higher altitude than at present [31-33]. Hamilton et al. [34] noted increases in Podocarpus, Olea, and Syzygium pollen at Ahakagyezi Swamp around this period. In Kashiru Swamp, a significant extension of Poaceae and Ericaceae, accompanied by a decline of all forest elements except Podocarpus, Maytenus, and Hypericum occurred [35]. Roche and Bikwemu [35] noted a cold and dry period centred around $2500 \mathrm{yr} \mathrm{BP}$ in the Kashiru area.

4.4. Period $2000-1000{ }^{14}$ C yr BP. The DUMU core showed a significant increase in coprophilous (dungi) fungi indicative of increased human impacts in the forest, including forest fires, cultivation, and grazing. In East Africa, a final dry interval on a millennia timescale occurred between 2000 and 1000 yr BP. Several lake sediment records show a dry period of about 300 year's length [36-40]. This brief summary of the paleoclimate record from eastern Africa reveals several regionally felt intervals, but with the length and character differing from one site to another. Differences between the records may illuminate the range of variability that is found in the lake proxy records and/or in the large uncertainties inherited in radiocarbon age models and/or in the ambiguity in the interpretation of the proxy data. In many records there is evidence of increased human impact on their environments. In this period many sites showed that the landscapes were subjected to frequent burning, with a period of increase in fire at ca. 1300-1600 AD [41], which coincides with an increased human population in the region. In more recent times, an increase in species typically found in humaninduced environments is found. The near shore vegetation indicates lower lake levels, suggesting that drier conditions dominated.

4.5. Period $1000-200{ }^{14} \mathrm{C}$ yr BP. The DUMU core showed a significant increase in coprophilous (dungi) fungi indicative of increased human impacts in the forest, including forest fires, cultivation, and grazing. DRM core showed that the local vegetation was influenced by stagnation of water on swampy floor resulting from fluctuating wet-dry episodes as this is also supported by fluctuating herbaceous pollen spectra. In East Africa, a 1,100-year rainfall-drought history for Kenya's Lake Naivasha, based on sediments, fossil diatoms, and midge species and numbers was recorded [36]. The data indicate that equatorial East Africa, over the past millennium, has alternated between contrasting climate conditions. There has been a significantly drier climate than today during the "Medieval Warm Period" (1000-1270) and a relatively wet climate during the "Little Ice Age" (1270-1850) that was interrupted by three prolonged dry episodes. During the end of a dry period that has been identified from both lake records at around $1400 \mathrm{AD}$, a famine, known as the Wamara drought (1400-1412 AD) occurred [42]. The Bacwezi Empire in western Uganda collapsed shortly thereafter, at around $1450 \mathrm{AD}$, and settlements declined as a combined result of 
drier conditions, overgrazing, and diseases [41, 43]. Following more humid conditions, new settlements were established in northern Uganda and East Africa generally experiencing a time of political stability and agricultural success. For example, a highly sophisticated irrigation system was developed in Engaruka in northern Tanzania-which today is a very dry region that cannot sustain a large population [44]. The next prolonged dry period can be observed from the lake records (not a perfect age match though) and is centred at around 1600-1625 AD. This period is near in time with a period that is known from oral traditions to have been one of extensive political instability, migrations, and famines, including the famine known as the Nyarubanga, at 1587-1589 $\mathrm{AD}$ [42]. An extreme drought in the 1620s may have resulted in the fall of the capital at Munsa in Uganda at 1700 AD [41, 45]. During this period, the Engaruka system, an extensive fossil irrigation system located in northern Tanzania, was initiated in the early 15 th century. It was in its most extensive use between $1620 \mathrm{AD}$ and $1720 \mathrm{AD}$ and it declined in the early 19th century. The period of humid conditions followed thereafter, the Engaruka system continued to expand during the wetter conditions that followed, and its maximum size most probably occurred at some time between 1680 AD and $1820 \mathrm{AD}$ [44], where in east Ukamba, Kenya, large settlements developed, possibly encouraged by favourable environmental conditions, the Kikuyu people expanded, and maize cultivation was initiated [37]. The third dry period observed from the lake records is contemporary with a famine known as the Lapanarat-Mahlatule drought (1760$1840 \mathrm{AD})$ [42]. At this time, famine and short-term drought struck Ukamba and agropastoral production declined. One response to the harsh environmental conditions could have been the beginning of trade in food staples between the Kamba and the Kikuyu [46].

4.6. Period $200{ }^{14} \mathrm{C}$ yr $\mathrm{BP}$ to Present. In this period, all cores demonstrate the stable recovery of the forest vegetation types with sharp reduction herbaceous vegetation indicative of dominance of mid-latitude forest types (submontane and lowland forests). Abundance of coprophilous (dungi) fungi is indicative of increased human impacts in the forest, including forest fires, cultivation, and grazing. Detailed records of hydrological changes that are based on lake sediments are available from Lake Naivasha, Kenya [36, 37], and northern Lake Victoria, Uganda, [21, 38, 47]. Peaks in the records indicate wetter conditions and trough drier ones, as deduced from lake-level changes in metres (Lake Naivasha) and the abundance of shallow water diatoms in percentage (Lake Victoria). A shorter temperature record, spanning the past 200 years, is available from stable isotope studies on corals outside the Kenyan coast [48]. The system was still active into the early 19th century when it fell into decline, probably due to a number of catastrophic events, such as imported diseases (smallpox), environmental deterioration due to population pressure, and increased Masaai aggression. Later at the wake of these events, some people took up irrigation at Engaruka. A drastic climatic dislocation is indicated for the last two decades of the 19th century, this is manifested by the abrupt drop of lake levels [49-51] and in the onset of glacier recession in East Africa [49]. Increasing atmospheric humidity accompanying the warming contributed to the accelerated ice wastage in the most recent decades of the 20th century [52]. This was forced by enhanced solar radiation due to diminished cloud cover accompanying the reduced precipitation; continuation of ice retreat beyond the early decades of the 20th century was favored by a warming trend $[53,54]$.

\section{Conclusion}

The climate system is a naturally complex dynamic that proved in the past and will continue to do so in the present and future cause effects that are both positive and negative to civilizations. For the negative part of global climate effects, understanding the past on time scales provides us with knowledge to forecast the magnitudes that do affect human life. At the present, anthropogenically-induced global climate changes, particularly, global warming will have major implications on future climate, but it is important to also bear in mind that climate will change even without anthropogenic impact. With the increased understanding of the regional and temporal patterns and causes behind climate processes, people have today the challenging possibility of applying this knowledge to plan for the future.

\section{Conflict of Interests}

The authors declare that there is no conflict of interests regarding the publication of this paper.

\section{Acknowledgments}

This research was partly funded by the Critical Ecosystem Partnership Fund (CEPF) Small Grant Programme for Building Research Capacity among Tanzanian and Kenyan students. This research has also been partly funded by the Marie-Curie Excellence programme of the European 6th Framework under Contract MEXT-CT-2004-517098 to Dr. Robert Marchant carried out under the York Institute for Ecosystem Dynamics (KITE), Environment department, University of York, United Kingdom. The following organisations in Tanzania are highly acknowledged for their support: Wildlife Conservation Society of Tanzania (WCST) (the Birdlife Partner in Tanzania) as part of Critical Ecosystem Partnership Fund (CEPF), Tanzania Wildlife Research Institute (TAWIRI), Amani Nature Reserve and Forestry and Beekeeping Division all under Ministry of Natural Resources and Tourism for logistical support.

\section{References}

[1] N. D. Burgess, T. M. Butynski, N. J. Cordeiro et al., "The biological importance of the Eastern Arc Mountains of Tanzania and Kenya," Biological Conservation, vol. 134, no. 2, pp. 209-231, 2007.

[2] J. C. Lovett, "Endemism and affinities of the Tanzanian montane forest flora," in Proceedings of the Eleventh Plenary Meeting of the Association for the Taxonomic Study of Tropical Africa, P. Goldblatt and P. P. Lowry, Eds., vol. 25 of Monographs in 
Systematic Botany from the Missouri Botanical Garden, pp. 591598, Missouri Botanical Garden Press, St Louis, Mo, USA, 1988.

[3] A. W. Diamond and A. C. Hamilton, "The distribution of forest passerine birds and Quaternary climatic change in tropical Africa," Journal of Zoology, vol. 191, no. 3, pp. 379-402, 1980.

[4] A. C. Hamilton, Environmental History of East Africa: A Study of the Quaternary, Academic Press, London, UK, 1982.

[5] C. T. Mumbi, R. Marchant, H. Hooghiemstra, and M. J. Wooller, "Late Quaternary vegetation reconstruction from the Eastern Arc Mountains, Tanzania," Quaternary Research, vol. 69, no. 2, pp. 326-341, 2008.

[6] M. Stuiver, P. J. Reimer, E. Bard et al., "INTCAL98 radiocarbon age calibration, 24,000-0 cal BP," Radiocarbon, vol. 40, no. 3, pp. 1041-1083, 1998.

[7] S. T. Iversen, The Usambara Mountains, North East Tanzania: Phytogeography of the Vascular Plant Flora, Almqvist \& Wiksell, 1991.

[8] J. Brunnthaler, "Vegetationsbilder aus Deutsch-Ostafrika: Regenwald von Usambara," Vegetations-Bilder, vol. 11, no. 8, pp. 43-48, 1914.

[9] M. Attems, "Permanent cropping in the Usambara Mountains," in Smallholder Farming and Smallholder Development in Tanzania, H. Ruthenberg, Ed., pp. 137-174, Weltforum, München, Germany, 1968.

[10] J. C. Lovett, "Tanzanian forest tree plot diversity and elevation," Journal of Tropical Ecology, vol. 15, no. 5, pp. 689-694, 1999.

[11] African Pollen Database (APD), 2004, http://www.ncdc.noaa .gov/paleo/apd.html.

[12] C. Caratini and P. Guinet, Eds., Pollen et Spores d'Afrique Tropicale, Center National de la Recherche Scientifique (CNRS), Center d'Etudes de Geographie Tropicale, Domaine Universitaire de Bordeaux, Talence, France, 1974.

[13] R. Bonnefille, "Atlas des pollens de Éthiopie. Principales espéces des forêts de montagne," Pollen et Spores, vol. 13, no. 1, pp. 15-72, 1971.

[14] R. Bonnefille and G. Riollet, Pollens des Savanes d'Afrique Orientale, Éditions du Center National de la Recherche Scientifique (CNRS), Paris, France, 1980.

[15] G. E. B. El Ghazali, "A study on the pollen flora of Sudan," Review of Palaeobotany and Palynology, vol. 76, no. 2-4, pp. 99-345, 1993.

[16] B. van Geel, "A palaeoecological study of holocene peat bog sections in Germany and The Netherlands, based on the analysis of pollen, spores and macro- and microscopic remains of fungi, algae, cormophytes and animals," Review of Palaeobotany and Palynology, vol. 25, no. 1, pp. 1-120, 1978.

[17] B. van Geel, J. Buurman, O. Brinkkemper et al., "Environmental reconstruction of a Roman period settlement site in Uitgeest (The Netherlands), with special reference to coprophilous fungi," Journal of Archaeological Science, vol. 30, no. 7, pp. 873883, 2003.

[18] E. C. Grimm, "CONISS: a FORTRAN 77 program for stratigraphically constrained cluster analysis by the method of incremental sum of squares," Computers \& Geosciences, vol. 13, no. 1, pp. 13-35, 1987.

[19] F. Gasse, "Diatom-inferred salinity and carbonate oxygen isotopes in Holocene waterbodies of the western Sahara and Sahel (Africa)," Quaternary Science Reviews, vol. 21, no. 7, pp. 737-767, 2002.

[20] P. Barker and F. Gasse, "New evidence for a reduced water balance in East Africa during the Last Glacial Maximum: implication for model-data comparison," Quaternary Science Reviews, vol. 22, no. 8-9, pp. 823-837, 2003.

[21] J. C. Stager, B. F. Cumming, and L. D. Meeker, "A 10,000year high-resolution diatom record from Pilkington Bay, Lake Victoria, East Africa," Quaternary Research, vol. 59, no. 2, pp. 172-181, 2003.

[22] R. A. Marchant and H. Hooghiemstra, "Rapid environmental change in African and South American tropics around 4000 years before present: a review," Earth-Science Reviews, vol. 66, no. 3-4, pp. 217-260, 2004.

[23] P. A. Barker, F. A. Street-Perrott, M. J. Leng et al., "A 14,000-year oxygen isotope record from diatom silica in two alpine lakes on Mt. Kenya," Science, vol. 292, no. 5525, pp. 2307-2310, 2001.

[24] P. A. Barker, R. Telford, F. Gasse, and F. Thevenon, "Late pleistocene and holocene palaeohydrology of Lake Rukwa, Tanzania, inferred from diatom analysis," Palaeogeography, Palaeoclimatology, Palaeoecology, vol. 187, no. 3-4, pp. 295-305, 2002.

[25] L. G. Thompson, E. Mosley-Thompson, M. E. Davis et al., "Kilimanjaro ice core records: evidence of holocene climate change in tropical Africa," Science, vol. 298, no. 5593, pp. 589593, 2002.

[26] M. R. Talbot and T. Lærdal, "The Late Pleistocene-Holocene palaeolimnology of Lake Victoria, East Africa, based upon elemental and isotopic analyses of sedimentary organic matter," Journal of Paleolimnology, vol. 23, no. 2, pp. 141-164, 2000.

[27] F. Chalié and F. Gasse, "Late Glacial-Holocene diatom record of water chemistry and lake level change from the tropical East African Rift Lake Abiyata (Ethiopia)," Palaeogeography, Palaeoclimatology, Palaeoecology, vol. 187, no. 3-4, pp. 259-283, 2002.

[28] J. Mworia-Maitima, "Vegetation response to climatic change in central Rift Valley, Kenya," Quaternary Research, vol. 35, no. 2, pp. 234-245, 1991.

[29] F. A. Street-Perrott and R. A. Perrott, "Holocene vegetation, lake levels and climate of Africa," in Global Climates since the Last Global Maximum, H. E. Wright Jr., J. E. Kutzbach, T. Webb III, W. F. Ruddiman, F. A. Street-Perrott, and P. J. Bartlein, Eds., pp. 318-356, University of Minnesota Press, London, UK, 1993.

[30] D. M. Taylor, "Late quaternary pollen records from two Ugandan mires: evidence for environmental changes in the Rukiga highlands of southwest Uganda," Palaeogeography, Palaeoclimatology, Palaeoecology, vol. 80, no. 3-4, pp. 283-300, 1990.

[31] J. A. Coetzee, "Evidence for a considerable depression of the vegetation belts during the upper pleistocene on the East African mountains," Nature, vol. 204, no. 4958, pp. 564-566, 1964.

[32] J. A. Coetzee, "Pollen analytical studies in East and Southern Africa," Palaeoecology of Africa, vol. 3, pp. 1-46, 1967.

[33] J. A. Coetzee, "Palynological intimations on the East African mountains," Palaeoecology of Africa, vol. 18, pp. 231-244, 1987.

[34] A. C. Hamilton, D. Taylor, and J. C. Vogel, "Early forest clearance and environmental degradation in south-west Uganda," Nature, vol. 320, no. 6058, pp. 164-167, 1986.

[35] E. Roche and G. Bikwemu, "Paleoenvironmental change on the Zaire-Nile ridge in Burundi, the last 2000 years: an interpretation of palynological data from the Kashiru Core, Ijenda, Burundi," in Quaternary Environmental Research on East African Mountains, W. C. Mahaney, Ed., pp. 231-244, Balkema, Rotterdam, The Netherlands, 1989. 
[36] D. Verschuren, K. R. Lalrd, and B. F. Cumming, "Rainfall and drought in equatorial east Africa during the past 1,100 years," Nature, vol. 403, no. 6768, pp. 410-414, 2000.

[37] H. Lamb, I. Darbyshire, and D. Verschuren, "Vegetation response to rainfall variation and human impact in central Kenya during the past 1100 years," The Holocene, vol. 13, no. 2, pp. 285-292, 2003.

[38] J. C. Stager, D. Ryves, B. F. Cumming, L. D. Meeker, and J. Beer, "Solar variability and the levels of Lake Victoria, East Africa, during the last millenium," Journal of Paleolimnology, vol. 33, no. 2, pp. 243-251, 2005.

[39] J. M. Russell, T. C. Johnson, and M. R. Talbot, "A 725 yr cycle in the climate of central Africa during the late Holocene," Geology, vol. 31, no. 8, pp. 677-680, 2003.

[40] M. L. Filippi and M. R. Talbot, "The palaeolimnology of northern Lake Malawi over the last $25 \mathrm{ka}$ based upon the elemental and stable isotopic composition of sedimentary organic matter," Quaternary Science Reviews, vol. 24, no. 10-11, pp. 1303-1328, 2005.

[41] P. Robertshaw and D. Taylor, "Climate change and the rise of political complexity in western Uganda," Journal of African History, vol. 41, no. 1, pp. 1-28, 2000.

[42] J. B. Webster, "Drought, migration and chronology in the Lake Malawi littoral," Transafrican Journal of History, vol. 9, pp. 7090, 1980.

[43] D. Taylor, P. Robertshaw, and R. A. Marchant, "Environmental change and political-economic upheaval in precolonial western Uganda," The Holocene, vol. 10, no. 4, pp. 527-536, 2000.

[44] J. Sutton, "Engaruka: the success \& abandonment of an integrated irrigation system in an arid part of the Rift Valley, c 15th to 17th centuries," in Islands of Intensive Agriculture in the Eastern Africa, M. Widgren and J. E. G. Sutton, Eds., Eastern African Studies, pp. 114-132, James Currey, 2004.

[45] B. J. Lejju, D. Taylor, and P. Robertshaw, "Late-Holocene environmental variability at Munsa archaeological site, Uganda: a multicore, multiproxy approach," The Holocene, vol. 15, no. 7, pp. 1044-1061, 2005.

[46] K. Jackson, "The dimensions of Kamba pre-colonial history," in Kenya before 1900: Eight Regional Studies, B. A. Ogot, Ed., pp. 174-261, East African Publishing House, Nairobi, Kenya, 1976.

[47] J. C. Stager, B. Cumming, and L. Meeker, "A high-resolution 11,400-yr diatom record from Lake Victoria, East Africa," Quaternary Research, vol. 47, no. 1, pp. 81-89, 1997.

[48] J. E. Cole, R. B. Dunbar, T. R. McClanahan, and N. A. Muthiga, "Tropical pacific forcing of decadal SST variability in the western Indian ocean over the past two centuries," Science, vol. 287, no. 5453, pp. 617-619, 2000.

[49] S. Hastenrath, The Glaciers of Equatorial East Africa, Reidel, Dordrecht, The Netherlands, 1984.

[50] S. E. Nicholson, "The nature of rainfall variability over Africa on time scales of decades to millenia," Global and Planetary Change, vol. 26, no. 1-3, pp. 137-158, 2000.

[51] S. E. Nicholson and X. Yin, "Rainfall conditions in equatorial East Africa during the nineteenth century as inferred from the record of Lake Victoria," Climatic Change, vol. 48, no. 2-3, pp. 387-398, 2001.

[52] S. Hastenrath and P. D. Kruss, "The dramatic retreat of Mount Kenya's glaciers between 1963 and 1987," Annals of Glaciology, vol. 16, pp. 127-133, 1992.

[53] G. Kaser and B. Noggler, "Observations on Speke Glacier, Ruwenzori Range, Uganda," Journal of Glaciology, vol. 37, no. 127, pp. 315-318, 1991.
[54] S. Hastenrath and L. Greischar, "Glacier recession on Kilimanjaro, East Africa, 1912-89," Journal of Glaciology, vol. 43, no. 145, pp. 455-459, 1997. 

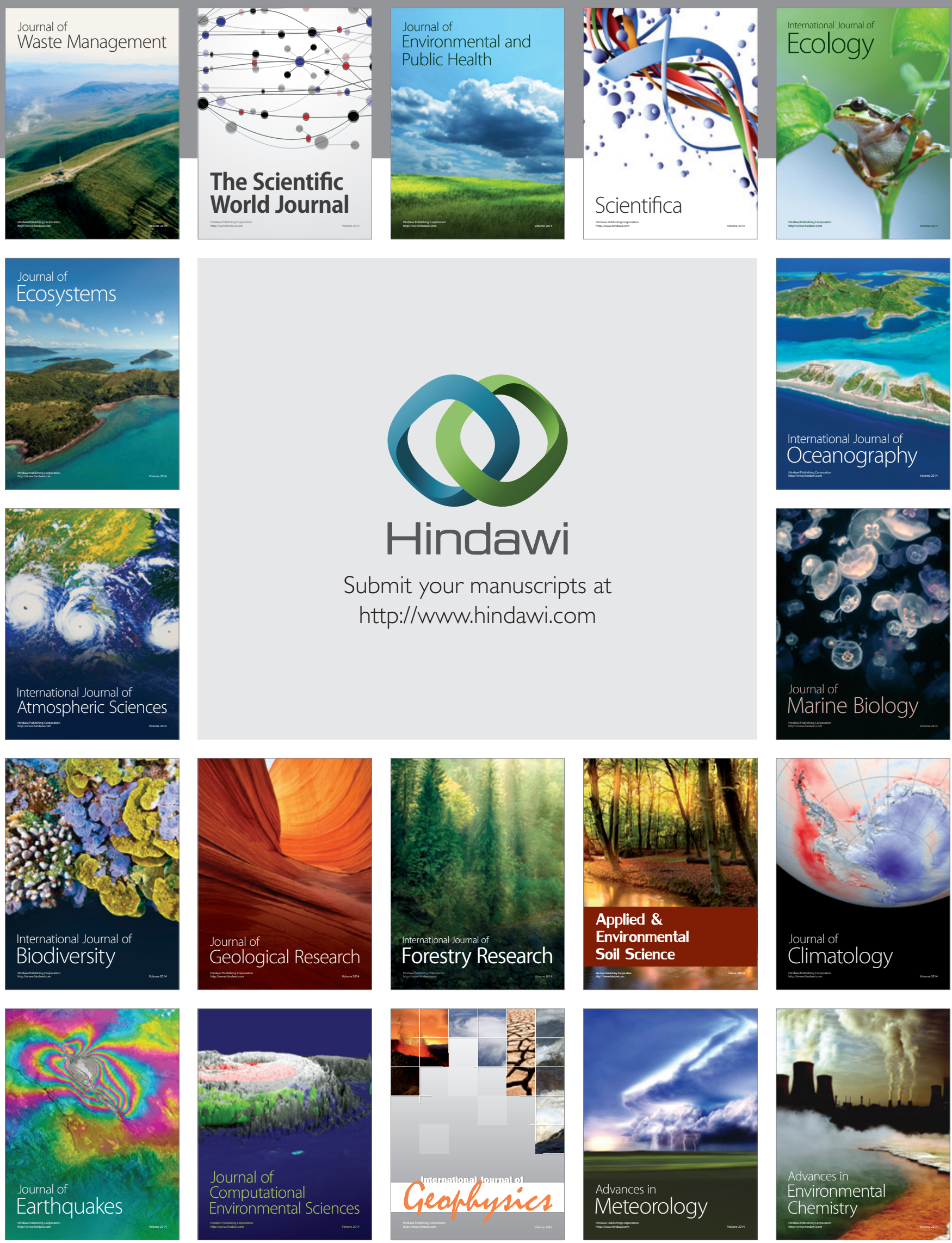